\title{
Inflammation, a key Factor in Cancer Ambush
}

\author{
Omolbanin Amjadi ${ }^{1}$, Alireza Rafiei ${ }^{1 *}$, Abolghasem Ajami ${ }^{1}$, Vahid Hosseini ${ }^{2}$, Hossein Asgarian-Omran ${ }^{1}$ \\ ${ }^{1}$ Molecular and Cell Biology Research Center, Department of Immunology, Faculty of Medicine, Mazandaran University of Medical Sciences, \\ Sari, Iran. \\ ${ }^{2}$ Department of Internal Medicine, Faculty of Medicine, Mazandaran University of Medical Sciences, Sari, Iran.
}

Received: 1 Feb 2014

Revised : 5 Mar 2014

Accepted: 15 Mar 2014

Corresponding Authors:

Alireza Rafiei

Molecular and Cell Biology Research Center, Department of Immunology,

Faculty of Medicine, KM 17

Khazarabad Road, Khazar Sq, Sari,

Iran.

Phone: +98-113543614

E-mail: Rafiei1710@gmail.com

\begin{abstract}
Inflammatory condition is the consequence of defensive mechanism of immune system against viral and bacterial infection, tissue injury, UV radiation, stress and etc. Persistently acute inflammation leads to chronic phase which is characterized by production of pro-inflammatory mediators from $\mathrm{T}$ cells. These molecules (e.g. IL-6, TNF- $\alpha$, IL-1 $\beta$ and IL-17) are mostly pleiotropic cytokines involved in multiple signaling cascades. NF- $\mathrm{KB}$, STAT3, and HIF-1 $\alpha$ are the major engaged pathways directing to several downstream targets associating with tumorigenesis and inflammation. Carcinogenesis processes such as DNA mutation/damage, proliferation, angiogenesis, apoptosis, and invasion are implicated to inflammation. Clearly there is a closely association between cancer and inflammation reported as "Seven Hallmark of Cancer". The elucidation of relationship between inflammation and cancer and their interaction may result in effective therapy and prevention. Gastric cancer is one of the main cancer involved in complex correlation of inflammation and cancer. Inflammation in gastric epithelium could trigger cellular transformation and promote invasion by inducing immune responses and utilizing signaling cascades. Gastric tumor microenvironment has inverse association by providing cytokines and inflammatory mediators. This closely relationship facilitates gastric tumor development and the induction of chronic inflammation in tumor microenvironment. The current review will focus on describing the possible and critical ways in which inflammation and cancer are linked together with specific view to gastric cancer and inflammation. Finally, it introduces some putative treatment generally used in this way in order to direct more attention for further exploration.
\end{abstract}

Keywords: Inflammation; Cancer; Gastritis; Gastric cancer; Cytokines; Chemokines; Signaling pathway

Please cite this article as: Amjadi O, Rafiei A, Ajami A, Hosseini V, Asgarian-Omran H. Inflammation, a key Factor in Cancer Ambush. Res Mol Med. 2014; 2 (2): 1-15

\section{Introduction}

The first association between inflammation and cancer came back to 1828 when a French surgeon Jean Nickolas Marjolin described the occurrence of squamous carcinoma in a post-traumatic chronically inflamed wound. In 1863, Dr Rudolf Virchow observed leukocytes in neoplastic tissues. He supposed that cancer was originated at the sites of chronic inflammation. These were the first step that provides evidences of possible relationship between Inflammation and cancer (1). Epidemiological data proved that over $25 \%$ of all cancers are associated with chronic infection and other types of inflammation (2). For example, it is suggested that chronic inflammation in prostate plays a key role in initiation and promotion of prostate cancer (3). Another study estimated that prostatitis has approximately $14 \%$ increase in the risk of prostate cancer (4). Colorectal cancer is associated with both ulcerative colitis and Crohn's disease; such patients have a higher risk of colorectal cancer than normal 
people without inflammatory bowel diseases (IBDs) (5). During liver inflammation, liver cells initiate growth and repair that are necessary for normal recovery of liver cells. Chronic inflammation is able to imbalance liver cells regeneration and replacement which led to disruption of hepatic structure and function. Long-term inflammation may progress to fibrosis, cirrhosis, and cancer. Hepatitis B (HBV) and hepatitis $\mathrm{C}(\mathrm{HCV})$ viruses are found in $75 \%$ of all patients with hepatocellular carcinoma (HCC) (6). Chronic pancreatitis increases 10-20-fold in the risk for pancreatic cancer development; this progression is due to chronic inflammatory process including stroma formation (7). Consistent results came from study that showed $H$.pylori-induced chronic gastritis has an important role in development of gastric cancer (8). Herein, we will focus on the main routes and mechanisms linking inflammation and cancer as well as point evidences supporting interaction between gastric inflammation and cancer. Finally, we will investigate the therapeutic effects of knowledge in the field of gastric inflammation-cancer connection in order to provide novel insight toward achieve the efficient treatments.

\section{Cancer and Inflammation}

Cancer and inflammation are linking to each other via two pathways; intrinsic and extrinsic. Inflammatory conditions such as secreting chemokines and cytokines increase cancer risk during extrinsic pathway while genetic alterations like activation proto-oncogene, inactivation tumor suppressor gene, and chromosomal instability participate in intrinsic pathway (9) (Figure 1).

\section{Inflammation: From acute to chronic phase}

The word inflammation is derived from Latin word of "inflammare" that means to set on fire (10). The inflammation is a non-specific complex of process coordinated response of tissues to injury. Inflammation process contains vascular permeability, active migration of blood cells and transmission of plasma constituents into inflamed tissues (11). Inflammation is divided into acute and chronic subgroups. Acute inflammation is the initial immune response that occurs in the first few hours following damage. This phase is characterized by increasing in blood flow though vasodilatation induces structural changes in the microvasculature and resulted in vascular permeability in which plasma fluid and proteins and leukocytes leave the circulation, leukocytes and inflammatory cytokines migrate from the microcirculation and are accumulated in the site of injury (12). Neutrophils are the most important leukocytes that migrate to injured state (13). Cytokines such as IL-1, TNF- $\alpha$ and IL-6 are associated with acute phase of inflammation (14). This short time systemic response has potential therapeutic effects, if inflammation lasts too long may lead to chronic phase (15). Chronic response is a dysregulated form of inflammation that localized in tissues. Both special humoral and cellular immune responses are developed during this phase. Different types of pro-inflammatory mediators are released and/or generated during chronic inflammation such as IL-4, IL-5, IL-6, IL-7, and IL-13 that mediating humoral responses and those mediating cellular responses; IL-1, IL-2, IL-3, IL-4, IL-7, IL-9, IL-10, and IL-12 (16). Persistence of chronic inflammation is involved in development of wide variety of diseases such as cardiovascular disease, diabetes, Alzheimer disease, arthritis, autoimmune diseases, and cancers (17). Gastritis is a group of inflammatory condition occurring in stomach lining caused by Helicobacter pylori infection, smoking, alcohol consumption, viruses, and etc. H. Pylori and Ebstein Barr virus (EBV) were detected in 75\% (18) and 10\% of gastric cancer, respectively (19). H. pylori are able to stimulate immune responses through macrophage activation. TNF- $\alpha$ induced in this way initiates Wnt signaling pathway contributing to gastric carcinogenesis (20). Chronic gastritis caused by $H$. pylori enhances IL-8 and neutrophils infiltration (21). IL-8 is the main cytokine expressed during acute phase in response to $H$. pylori infection and up-regulated in chronic phase. IL-8 contributes in apoptosis, proliferation, growth, and vascolarization in gastric tumors (22). IL-8 and Gro $\alpha$ are key molecules in neutrophils attraction and transition from gastric mucosal vessels to local inflammatory sites in epithelium (23). The great direct relationship between $H$. pylori infection, neutrophils activation, chronic gastritis, and intestinal metaplasia stage is confirmed in Tanko et al study (24). In addition to generation of several chemokines by neutrophils, they induces oxidative damage to gastric mucosa by production of reactive oxygen specious (ROS). Thus H. pylori causes persistent and localized inflammation (25). There are polymorphisms in iNOS gene in patients with $H$. pylori infection that create a great risk for developing gastric cancer (26). $H$. pylori infection is associated with increased production of proinflammatory cytokines such as TNF- $\alpha$, IL-1 $\beta$, IL- 6 , IL-8, and IL-12. The secretion of proinflammatory cytokines during chronic gastritis and peptic ulcers may lead to gastric cancer (27). These are confirmatory evidences that prove inflammation participate in cytokines production and cancer development. Taken together, inflammation is characterized by infiltration of immune cells such as macrophages, lymphocytes, and plasma cells that lead to tissue damage, fibrosis, and angiogenesis (28). On the other hand, proinflammatory molecules such 
as cytokines, iNOS, ROS, NF- $\kappa \mathrm{B}$ are increased (29). These molecules trigger pathways in which transcription factors and inflammatory mediators are transcribed. These transcription factors initiate carcinogenic processes containing: proliferation, apoptosis, angiogenesis, invasion, and metastasis. Thus inflammation promotes cancer progression by provide compounds that induce mutations and proper microenvironment for tumor growth (Figure 1).

\section{Cancer}

Cancer is an abnormal cellular behavior in which normal cells continue to their unlimited proliferation and spread to distant location of the body during a process called metastasis (30). Although proliferation is the perquisite step in embryogenesis, tissue functions and also tumorigenesis, cancer cells escape from normal homeostatic growth control. This is the consequence of loss of tumor suppressive ability and gain oncogenic properties (31). Oncogenes are activated form of normal cellular gene called "protooncogene" derived from genetic damages direct normal cells toward transformation and malignancies (32). K-ras is one of oncogenes expressed in cancerous tissues such as gastric epithelium. Oncogenic mutations in K-ras may lead to promote chronic inflammation by production of cytokines and soluble mediators. Furthermore, it is found that mutant K-ras can induce Helicobacter felis infection in gastric epithelium and resulted in chronic inflammation. Helicobacter-related infection would play an important role in gastric cancer development from normal epithelium to advanced form. Thus Kras oncogenic mutations could progress gastric cancer by Helicobacter-induced infection (33). It is demonstrated that Ras oncogenes are able to secrete CXCl-8/IL-8 which is critical factor in inflammation and neovascularization (34) especially in gastric cancer as implies before. N-myc downstreamregulated gene 1 (NDRG1) is overexpressed in gastric cancer with a poor prognosis. NDRG1 significantly increases angiogenesis and metastasis of gastric tumors through IL-1 secretion in JNK/AP1dependent pathway. It also induces angiogenic CXC chemokines in gastric cancer cells (35). These evidences confirmed the possible role of oncogenederived inflammatory cytokines in several process of tumorigenesis. The accumulation of mutation/ alteration in these genes resulted in cancer development during multi step process of carcinogenesis. Carcinogenesis processes including DNA damage, DNA synthesis, destruction in repair pathway, apoptosis inhibition, and angiogenesis promotion are associated with chronic inflammation (36).

\section{Inflammatory cells in cancer development}

Macrophages and $\mathrm{T}$ cells are the main part of immune response that are the most frequently cells found in tumor microenvironment (37). Macrophages are one of the main immune cells that take part in initiation, maintenance, and resolution of inflammation. They produce a wide range of cytokines (38). Macrophages differentiate into two subtypes named M1 which classically activated and M2 activated alternatively. Tumor-associated macrophages (TAMs) represent M2 phenotype with high content and poor prognosis in tumors (39). TAMs are the major components of inflammation that has a duel role in tumorigenesis. Besides its role in killing tumor tissues, they produce IL-10 (40), IL-1, prostaglandin E2, urokinase-type plasminogen activator (41), and also express VEGF (42). Moreover, they can secrete growth factors such as PDGF, TGF- $\beta$ and members of FGF family that act as pro-ongiogenic mediators in different cancers (43). TAMs are capable of degrading extra cellular matrix and facilitate tumor migration, metastasis and stimulate angiogenesis by secreting matrix metaloprotease 2 (MMP-2), MMP-7, MMP-9, MMP-10, and cyclooxygenase-2 (44-46). In addition TAMs connect inflammation to cancer by induction TNF- $\alpha$ and iNOS. The importance of TAM in gastric tumor development makes a close relationship between TAM infiltration determines tumor cells invasion and metastasis and also the clinical grade and stage of gastric cancer (47).

$\mathrm{T}$ lymphocytes are divided into two groups on the basis of their receptors: $\gamma \delta$ and $\alpha \beta$ (48). $\alpha \beta$ T cells generally express $\mathrm{CD}^{+}$(CTL) or $\mathrm{CD}^{+}$helper (Th) cells (49) including Th1, Th2, Th17, and regulatory $\mathrm{T}$ ( $\mathrm{T}$ reg) (50). The presence of increased number of Tlymphocyte subsets in different cancers demonstrated the relationship between immune cells and cancers. Many studies proved the possible relationship between $\mathrm{CD}^{+}$and $\mathrm{CD}^{+}$and different types of cancers such as skin, renal, colorectal cancer, and Hodgkin's lymphoma (51-54). T lymphocytes subsets are able to produce different cytokines such as IL-2, IL-4, IL-6, IL-10, TNF- $\alpha$, IFN- $\gamma$, COX-1, and COX-2 associating with malignant diseases (55). Different human and animal model studies revealed that $\mathrm{CD}^{+}$ $\mathrm{T}$ cells are the main part of the immune cells infiltrating during $H$. pylori-induced chronic gastritis (56). Obviously long-term exposure to $H$. pylori and persistent immune response develop inflammation to invasive phase. Regulatory $\mathrm{T}$ cells (Treg) is a part of $\mathrm{CD}^{+} \mathrm{T}$ cells that is involved in regulation of immune response, self tolerance, immune homeostasis, and differentallergic, infectious diseases and cancers (57). Treg cells $\left(\mathrm{CD}^{+} \mathrm{CD} 25^{+} \mathrm{FOXP} 3^{+} \mathrm{T}\right.$ cells $)$ areknown as immunosuppressor of tumor cells caused tumor growth and development and cancer treatment failure. 
Tumor cells may activate Treg cells (tumor Treg cells) in tumor microenvironment which destruct immunity against cancer. Tumor-generated TGF- $\beta$ increases the growth and proliferation of Treg and leads to its differentiation from naïve $\mathrm{CD} 4^{+} \mathrm{CD} 25-\mathrm{T}$ cells. In addition other co-stimulators such as CD80/CD86 or CD70 are expressed for conversion of naïve $\mathrm{T}$ cells into Treg. Tumor Treg prevent NK cells, $\mathrm{CD}^{+}$, and $\mathrm{CD}^{+} \mathrm{T}$ cells in order to promote tumorigenesis. High level of Treg was reported in different types of cancers such as lung, ovarian, colon, and gastric (58). Increased $\mathrm{CD} 4^{+} \mathrm{CD} 25^{+} \mathrm{T}$ cells are correlated with poor prognosis of gastric cancer. This level is reduced after effective treatment (59). The level of $\mathrm{CD} 4^{+} \mathrm{CD} 25^{+} \mathrm{T}$ cells was associated to severity of gastric carcinogenesis (60). This not only confirms the role of Treg cells in gastric carcinoma but also shows the direct relationship of Treg levels with gastric stages. Another study investigated the role of $H$. pylori infection in gastric cancer promotion, $H$. pylori persistence is formed as the result of gastric inflammation and its-relating immune response. On the other hand, regulatory immune cells such as Treg cells are involved in immune responses and bacterial infection (61). Neutrophils are group of inflammatory initiator leukocytes that migrate to sites of inflammation. Their role in cytokine and chemikone production intensifies humoral immune response (62) and promotes inflammation. Furthermore, in tumor microenvironment several types of chemokines and cytokines are secreted by tumor cells that attract neutrophils and other leukocytes (63). These tumor associated-neutrophils (TANs) are the main parts of leukocytes recruited in cancer (64). Patients, who affected to metastatic form of cancer, reveal high levels of neutrophils in their peripheral blood (65). The main mechanisms of neutrophils participation in tumorigenesis are included secreting cytokines and chemokines (IL-6, IL-1 $\beta$, TNF- $\alpha$, IL-12), inducing genotoxicity by producing ROS, generation of basement membrane-degrading proteinases and facilitating tumor invasion and metastasis, activation of neutrophil-derived MMP-9 that is accommodated in a special secondary granules, and production of neutrophil elastase (66). An Elastolytic enzyme leads to un-controllable proliferation and tumor growth. It is found that there is an association between $H$. pylori localization and increased neutrophils transition and infiltration (67).

Mast cells are one of the key immune cells associated with tumor-related inflammation. Besides their role in regulation of tumor inflammation and autoimmune diseases, they act as tumor promoting cells by releasing stimulatory mediators (68). Regarding the fact that inflammation plays a key role in tumor initiation, promotion and invasion, mast cell transition to tumor may increase tumor cells growth. Stem cell factor (SCF) and its receptor (c-Kit) expressed on mast cells take part in mast cell differentiation, migration, maturation, and activation. Activated mast cells are able to secrete various proinflammatory molecules and overexpression of IL-17 in tumor cells. This form of mast cells implicated in tumor microenvironment remodeling, enhancing NF- $\kappa \mathrm{B}$ and AP-1 activities and inhibits $\mathrm{T}$ and NK cells (69). There is a close association between angiogenesis, mast cell numbers and gastric tumor growth. Mast cells are one of the immune cells that secrete proangiogenic molecules and enhance neovascularization. Mukheriee et al showed that mast cells density in benign gastric tumor is higher than controls. Moreover, mast cells increase in welldifferentiated gastric cancer compared with lessinvasive form (70). VEGF is a growth factor participating in angiogenesis especially in gastric cancer. VEGF and its receptor (VEGFR-2) are highly expressed in gastric tumor cells (71). Thus mast cells play an important role in gastric tumor metastasis and invasion by producing VEGF and preparing new vessels.

\section{Signaling Pathway \\ $N F-\kappa B$}

Nuclear Factor- $\kappa \mathrm{B}$ is the most important factor linking inflammation to cancer. This dimeric transcription factor exists in cytoplasm in its inactivation form along with $\mathrm{I} \kappa \mathrm{B}$ as inhibitor (72). Stimulation such as cytokines lead to I $\mathrm{B}$ phosphorylation, remove its inhibitory effect and resulted in NF-кB nuclear localization (73); therefore $\mathrm{NF}-\kappa \mathrm{B}$ trigger its downstream signaling pathway including immune-mediating genes and inflammatory genes, anti-apoptotic genes, cell proliferation regulating genes, and genes encoding negative regulators of NF- $\kappa \mathrm{B}$ (74). Majority the pathway of $\mathrm{NF}-\kappa \mathrm{B}$ is proinflammatory signaling pathways that activate NF- $\kappa \mathrm{B}$ via pro-inflammatory cytokines and direct to activation of cytokines and chemokines such as IL-6, TNF- $\alpha$, IL-8 and adhesion molecules, MMP, COX2, and iNOS (75). Moreover, NF- $\kappa \mathrm{B}$ acts as a key factor in carcinogenesis by suppressing apoptosis, enhancing proliferation, and disrupts the balance between programmed death and proliferation toward uncontrollable cell growth. c-Myc and cyclin D1 are two proto-oncogenes expressed in response to $\mathrm{NF}-\kappa \mathrm{B}$ activation and participating in tumor development by constant stimulation (76). NF- $\kappa \mathrm{B}$ also contributes in the last stage of carcinogenesis via increasing the angiogenesis and metastasis. MMPs, IL- 8 and VEGF are targeted genes promoted by NF$\kappa \mathrm{B}$ (77-78) (Figure 2). H. pylori infection is one of 
stimuli way to activate NF- $\kappa \mathrm{B}$ in gastric cancer. This cascade led to generation of pro-inflammatory cytokines (IL-8, TNF- $\alpha$, INF- $\gamma$, and IL-6) (79-81).
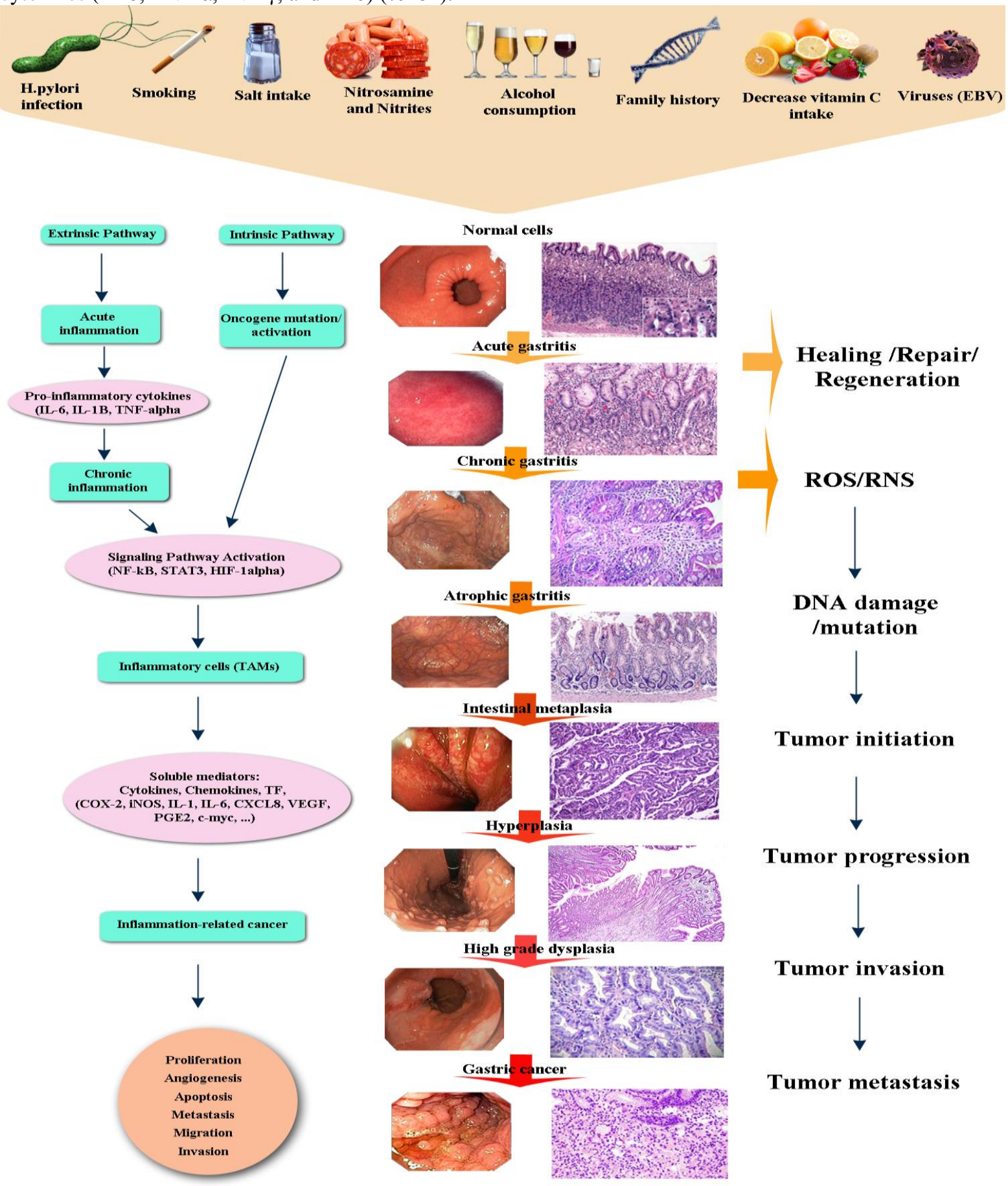

\section{Healing /Repair/ Regeneration}

ROS/RNS

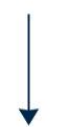

\section{DNA damage \\ /mutation}

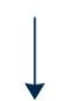

Tumor initiation

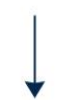

Tumor progression<smiles>[Te][Te]</smiles>

Tumor invasion<smiles>[13CH][13CH3]</smiles>

Tumor metastasis

Figure 1. From gastritis to gastric cancer. Several environmental (cigarette smoke, bacterial and viral infection, foods) and genetic factors predispose people to gastric cancinogenesis. Acute phase (acute gastritis) is characterized by production of proinflammatory cytokines. Persistent acute response may lead to chronic phase (chronic gastritis). During chronic phase, ROS, cytokines, and transcription factors are produced. They initiate potent signaling cascades (NF-kB, STAT3, and HIF-1 $\alpha$ ) with numerous targets such as VEGF, cytokines, chemokines, c-myc, Bcl2, COX-2, iNOS and etc. These downstream targets are able to induce growth, angiogenesis, and metastasis and inhibit apoptosis. Immune responses activated as the result of chronic process develop chronic gastritis to atrophy, intestinal metaplasia, hyperplasia, dysplasia, and finally invasive form of gastric cancer with metastatic potential to other sites. 
Another study implies to important role of $H$. pylori infection in NF- $\kappa \mathrm{B}$ activation and induction of growth factors and cytokines network in gastric carcer. Several genes are expressed as an NF- $\mathrm{BB}$ downstream target during process of gastric carcinogenesis (IL-1, IL-6, IL-8, TNF- $\alpha$, VEGF, COX2, iNOS, cell-cycle regulator, MMP2, MMP9, and adhesion molecules) (82). The results of these study confirmed NF- $\mathrm{KB}$ activation during inflammatory process and its role in carcinogenesis. Therefore, NF- $\mathrm{kB}$ acts as a mediator of inflammation progress, expression regulator of inflammatory molecules and also is a tumor promoter in inflammation.

\section{STAT3}

Signal Transducer and Activator of Transcription 3 (STAT3) is a transcriptional factor mediating signaling pathway with survival, proliferation, and angiogenesis. Different cytokines releasing during inflammation like IL-1, IL-6, TNF- $\alpha$, IL-22, and IL11 can activate STAT3 (83). Following STAT3 activation, it regulates the expression of different genes involving in cell growth/proliferation and apoptosis (Figure 2). The role of STAT3 in colon, gastric, and liver cancers confirm its carcinogenic ability (84). Persistently, activated STAT3 mediates tumor-promoting inflammation through $\mathrm{NF}-\mathrm{\kappa B}$ and IL-6/gp130/JAK pathways. The hyperactivation of STAT3 is seen in $50 \%$ of human gastric cancer cases (85). Increased level of IL-6 as the result of STAT3 activation is correlated with tumor development in neoplastic stomach tissue (86). Therefore STAT3 is a possible transcription factor linking inflammation to cancer.

\section{$H I F-1 \alpha$}

Hypoxia-inducible factor 1-alpha (HIF-1 $\alpha$ ) is a transcription factor regulating oxygen homeostasis (87). HIF-1 $\alpha$ transcription is regulated by two pathways: oxygen dependent and inflammatory stimuli. It activates under condition of low oxygen tension. HIF-1 $\alpha$ activation and transcription is necessary for expression of wide variety of target genes involved in oxygen homeostasis, angiogenesis, metabolism, cell proliferation and viability, tissue remodeling, and erythropoiesis (88). Furthermore, pro-inflammatory cytokines such as IL- $1 \beta$ and TNF- $\alpha$ and also growth factors and bacterial products can increase transcriptional activity of HIF- $1 \alpha$ through NF- $\kappa B$ stimulation (89). HIF-1 $\alpha$ activated during hypoxia may induce COX-2 that resulted in increased PGE2 level. PGE2 contributed in tumor growth and survival and trigger angiogenesis. PGE2 mediates feedback loop via initiating MAPK signaling pathway resulting in an increase of HIF- $1 \alpha$ transcriptional activity (90). It is also demonstrated that IL-1 $\beta$ - produced COX-2/PGE2 pathway lead to activate HIF-1 $\alpha$ (91). The role of HIF- $1 \alpha$ in tumor extension, angiogenesis, and metastasis is performed through transcription of VEGF that increase vascular permeability, induce endothelial cell proliferation, leukocyte adhesion, and regulate neovessel lumen diameter (92) (Figure 2). The study on human gastric cancer TMK-1 cells suggested that the inhibition of HIF-1 $\alpha$ activity affect tumor proliferation, angiogenesis, and vessel maturation. The occurrence of this effect is due to direct relationship between HIF-1 $\alpha$ expression and VEGF (93).

\section{Nrf2}

Nuclear factor-erythroid 2 p45 (NF-E2)-related factor 2 (Nrf2) is a major transcription factor associated with responding to oxidative stress by activating protective antioxidant and detoxifying enzymes. Nrf2 enhances antioxidant activity and protects against pulmonary fibrosis (94). This regulatory effect is done by binding Nrf2 to antioxidant responding element (ARE) in the promoter of target gene encoding phase II detoxification and antioxidative defense enzymes. Beside the protection effect again ROS, Nrf2 has anti-inflammatory effects by regulating target genes involve in acute inflammation (95). Genetic polymorphisms were indentified in $\mathrm{Nrf} 2$ gene that increases the progression of gastric inflammation to gastric cancer (96).

\section{NFAT}

NFAT (Nuclear Factor of Activated T cell) is an immune-regulatory protein activated during the initiation phase of tumor formation by an unknown mechanism. The oncogenic effects of NFAT rely on cell type and tissue background (97). This transcription factor is expressed in T cells, mast cells, NK cells, and in certain monocytes, macrophages, and lymphoid tissues. NFAT-regulated effects result in production of pro-inflammatory genes. These in turn exacerbate the pathogenesis of inflammatory disorders such as inflammatory bowel disease (IBD) (98-99) Rheumatoid arthritis (RA) (100) and systemic lupus erythematosus (SLE) (101-103). Inhibition of NFAT attenuates the rise in Th2 antibody and IL-4 production which leads to arrest the allergic airway inflammation. Thus Th2 immune responses require to NFAT activation in $\mathrm{CD}^{+} \mathrm{T}$ cells (104).

NFAT proteins are regulated by phosphatase calcineurin activation which leads to NFAT nuclear localization. Upon NFAT binding to its target site, the cytokines IL-2, IL-4, IL-5, IL-13, IFN- $\gamma$, TNF- $\alpha$, the cell surface proteins CD40 ligand (CD40L), Cytotoxic T-Lymphocyte Antigen 4 (CTLA-4), Fas 
ligand (FasL), COX-2, and Cyclin-dependent kinase 4 (CDK4) are induced. These factors are involved in cell cycle machinery, apoptosis, angiogenesis, cell growth and proliferation and invasion. In addition
NFAT may act corporately with proto-oncogenes including: c-Fos, c-Jun (AP-1), and Egr protein (105106) (Figure 2).

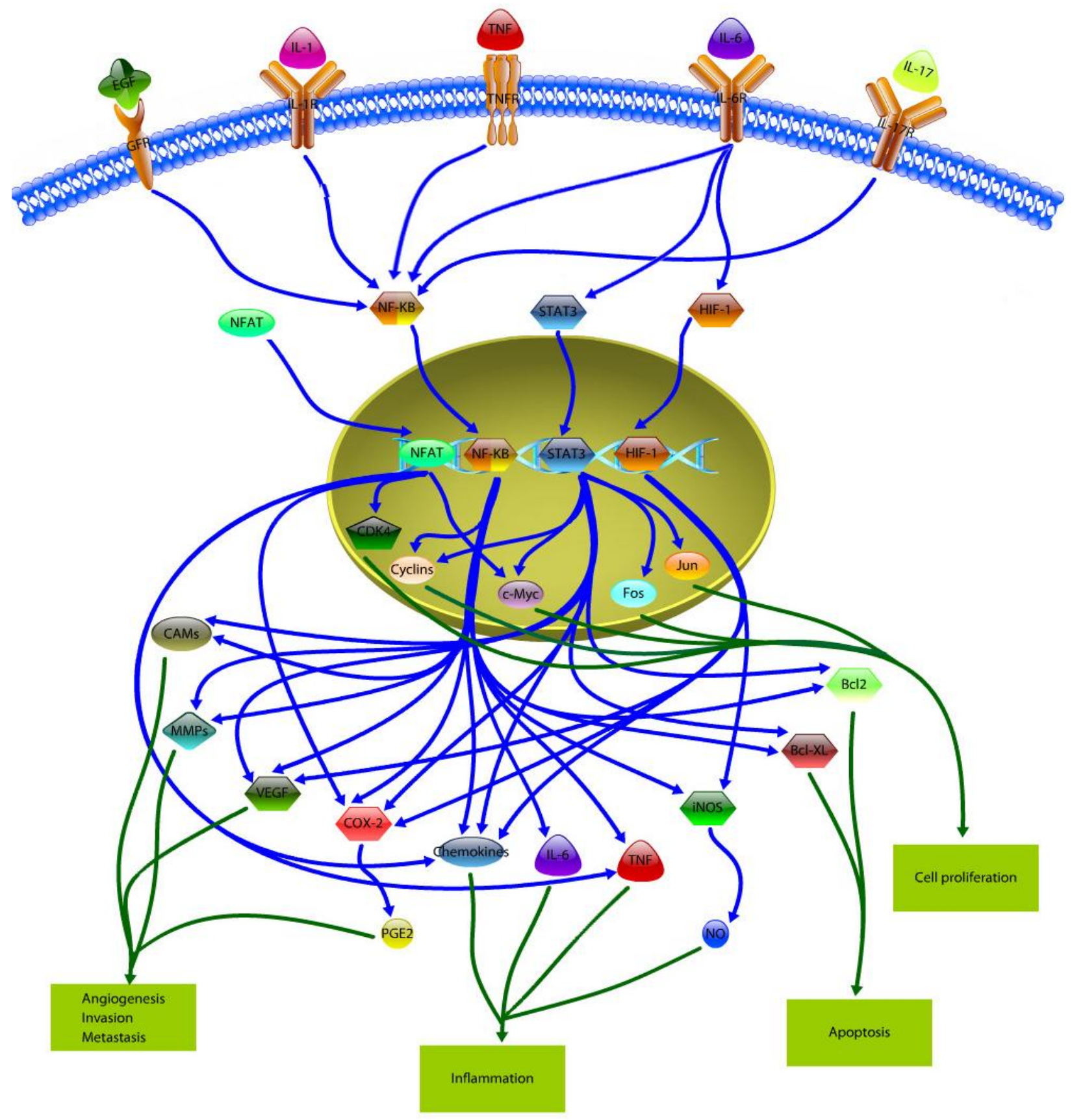

Figure 2. Inflammation-related cancer pathways. Chronic infection stimulates wide range of cellular responses upon activation of the signal transduction pathways such as NF- $\mathrm{BB}$, STAT3, and HIF-1 $\alpha$. The derived-inflammatory mediators, transcription factors, antiapoptotic factors, and others mediate different stages in carcinogenesis processes and inflammation. 
The role of NFAT proteins in regulation of different types of cancers is summarized in Pan et al study (107). CagA positive H. pylori-induced chronic infection increases the risk of developing chronic gastritis to gastric adenocarcinoma. CagA activates NFAT in gastric epithelium by phosphorylation and thereby localizes it in nucleus. The role of NFAT in growth and differentiation is related to disease resulting from $H$. pylori infection (108).

\section{Chemokines and Cytokines}

Chemokine are a major part of cancer- related inflammation. Chemokines are classified into four groups according to positions of key conserved cystiene residues: $\mathrm{C}, \mathrm{CC}, \mathrm{CXC}$, and $\mathrm{CX} 3 \mathrm{C}$. They are mainly identified as inflammatory mediators recruiting leukocytes (neutrophils and monocytes) in inflammation site and tumor. CXC and CC chemokines and their receptors are associated with tumor growth/proliferation and migration (109). Chemokines are involved in tumor growth and development by participating in angiogenesis and metastasis processes. Chemokines are capable of inducing the expression and activation of several MMPs especially MMP-9 resulted in extracellular matrix degredation and enhance tumor invasion (110). Gene expression profiling detects increased levels of CXCR4 in gastric cancer. In addition CXCR4 is capable of activating MMP-7 and MMP-9, while it up-regulate MMP2 and MMP-7 along with CXCR12 in gastric carcinoma (111). Several cytokines and pathways are responsible for chemokine production; IL-1, TNF- $\alpha$, NF- $\kappa$ B, JAK/STAT, and AP-1 (112). NF- $\kappa$ B is one of key pathway that modulates the transcription of chemokines including: CXCL1, $-2,-3,-5,-8,-9,-10$, and -12 , and CCL2, $-3,-4,-5,-11$, and -17 . Since this pathway is a well documented way for cell growth, angiogenesis, metastasis, and apoptosis; such chemokines regulates different processes of carcinogenesis (113). Following $H$. pylori infection, CXCR1 and CXCR2 are expressed in gastric cancer. TNF- $\alpha$ positively affects on secretion of CXCR4 in $H$. pylori-infected gastric cancer (114). Chemokines facilitate tumor infiltrating leukocytes and develop tumor cell homing to metastasis. CCR7 found in gastric and other types of cancers is able to induce metastasis (115). H. pylori -associated infection lead to multiple stages of gastric carcinogenesis. High level of T-cell infiltration is seen in $H$. pylori inflammatory site in gastric epithelium. This T-cell migration is a key step in increasing the gastric inflammation which in turn leads to gastric cancer. It is found that the complex of CCL20 and CCR6 is implicated in $\mathrm{CD}^{+} \mathrm{T}$ cells infiltration during gastritis caused by $H$. pylori (116).
iNOS

Inducible Nitric Oxide Synthase (iNOS), lead to generate nitric oxide (NO), overexpresses in many different types of malignancies and involved in various inflammatory processes (117). Cytokines such as TNF- $\alpha$ and IL- $1 \alpha$ are capable of inducing and then trans-activating iNOS by NF- $\kappa \mathrm{B}$ (118) (Figure 2). Nitric oxide produced by iNOS mediates carcinogenic process by inducing DNA damage, p53 mutation or loss resulted in $\mathrm{COX} 2$ activation and angiogenesis, tumor growth, migration, invasion, and metastasis (119). iNOS expression was detected at increasing frequency in several types of tumor such as colon, lung, oropharynx, reproductive organs, breast, and central nervous system but also plays a key role in the occurrence of chronic inflammatory diseases (120). High iNOS expression levels were detected in gastric mocusa of $H$. pylori-positive patients. H. pylori-induced IL-1, 6, 8, and TNF- $\alpha$ are involved in inflammation. IL-1 and TNF- $\alpha$ could also overexpress iNOS in gastric mocusa (121).

COX-2

Cyclooxygenase (COX)-2 is the inducible type of the prostaglandin synthase enzyme (122) which involving in catalyzing the conversion of arachidonic acid to various types of inflammatory and physiological mediators, including prostaglandins and thromboxane (123). The expression of COX-2 is induced by both proinflammatory cytokines (IL-1 $\beta$, TNF- $\alpha$, EGF) and mutagenic factors [Figure 2]; but also antiinflammatory cytokines such as IL-4, IL-10, and TGF- $\beta$ and dexamethasone and NSAIDs suppress COX-2 expression. The activity of COX-2 resulted in production of $\mathrm{PGE}_{2}$ and $\mathrm{PGI}_{2}$ that lead to promote tumor growth by their angiogenic activity. In addition, COX-2 may increase malondialdehyde derivative and up-regulate $\mathrm{Bcl}_{2}$ protein. Malondialdehyde is produced during lipid peroxidation and prostaglandin and involved in genomic instability. $\mathrm{Bcl}_{2}$ is an antiapoptotic factor suppressing apoptosis by inhibiting mitochondrial cytochrome c release and prevents caspase activation (124). The overexpression of COX-2 is a key event in the early stage of gastric carcinogenesis (125). The elevated level of COX-2 is investigated in gastric cancer by mechanisms: $H$. pylori infection, mutation in tumor suppressor genes and activation of $N F-\kappa B$ cascade. COX-2 is associated with proliferation, apoptosis, angiogenesis, metastasis, and invasion during gastric cancer progression (126).

$T N F-\alpha$

Tumor necrosis factor (TNF- $\alpha$ ) is an important inflammatory cytokine initially identified for its anticancer property to induce rapid haemorrhagic 
necrosis of experimental cancers (127). TNF- $\alpha$ participates in all process of carcinogenesis. TNF- $\alpha$ stimulates tumor initiation and promotion via activation of $\mathrm{NF}-\kappa \mathrm{B}, \mathrm{PKC} \alpha$, and $\mathrm{AP}-1$ signaling pathway. TNF- $\alpha$ enhances tumor cell growth and survival without differentiation through NF- $\kappa \mathrm{B}-$ dependent pathway. It recruits angiogenic factors such as IL-8 and VEGF to enhance angiogenesis in JNK and AP-1 dependent manner (Figure 2). TNF- $\alpha$ could increase tumor cell invasion and enhance cell migration and metastasis mediated through upregulation of NF- $\mathrm{NB}, \mathrm{JNK}$ and induction of MMPs and EMT acceleration (128). Following the different pathogenic stimuli, TNF- $\alpha$ induces inflammatory mediators and proteases regulating inflammatory responses (129). Therefore, TNF- $\alpha$ secreted by inflammatory cells in tumor microenvironment contributes in both tumorigenesis and inflammatory process. H. pylori is a protean stimulator of TNF- $\alpha$ which in turn increase the expression of CXCR4 in gastric cancer (130).

\section{$I L-6$}

Interleukin (IL)-6 is a pleiotropic cytokine mediating inflammation processes and activating different cell types through signaling pathway. IL-6 binds to its common signaling receptor, gp130, triggers JAK/STAT pathway (131). STAT pathway is well known in its ability to link cytokine signal to cellular transcriptional events. STAT protein regulates many critical processes in carcinogenesis including cellcycle progression, apoptosis, tumor angiogenesis, tumor-cell invasion, and metastasis, and tumor-cell evasion of the immune system (132) [Figure 2]. A study on AGS gastric cancer cells demonstrated that treatment with IL-6 resulted in AGS cell motility and invasion through c-Src/RhoA/ROCK signaling pathway (133). Thus IL-6 acts as a main regulator of tumor-associated inflammation and tumorigenesis.

\section{IL-17}

Interleukin (IL)-17 is a new subset of cytokine mainly generated by $\mathrm{CD}^{+} \mathrm{Th} 17$ cells. Its ability to stimulate the expression of inflammatory mediators including TNF- $\alpha$, IL-6, and IL-1 $\beta$ (134) classified it as a proinflammatory cytokine (Figure 2). Furthermore IL-17 is over-expressed in many inflammatory diseases like airway inflammation, rheumatoid arthritis, intraperitoneal abscesses and adhesions, inflammatory bowel disease allograft rejection, psoriasis, cancer, and multiple sclerosis (135). On the other hand the elevated IL-17 expression level is found in many types of malignancies including ovarian, cervical, breast, hepatocellular carcinoma, esophageal, gastric cancers, and CRC (136). There are several proposed mechanisms in which IL-17 can promote tumorigenesis; IL-17 stimulates the production of angiogenic factors such as GE1, PGE2, VEGF, keratinocyte-derived chemokine (KC), and macrophage inflammatory protein-2 (MIP-2) from tumor cells and enhance angiogenesis (137). IL-17 may activate JAK/STAT3 pathway via IL-6 production and resulted in tumor growth and survival (138) (Figure 2). IL-17 plays a paradoxical role (139), since it increases tumor cytokines production and has a partial anti-tumor activity. In the latter activity, IL-17 acts through promoting the activity of $\mathrm{CD}^{+}$and $\mathrm{CD}^{+} \mathrm{T}$ cells and immune response (140). Single nucleotide polymorphisms (SNPs) of the IL17 gene associated with cancer risk (141-142). A new study demonstrated the significant association of G197A polymorphism in IL-17A promoter to gastric cancer (143).

\section{$I L-1 \beta$}

Interleukin-1 $\beta$ (IL-1 $\beta$ ) is a proinflammatory cytokine up-regulated in various types of cancers: breast, colon, lung, head and neck cancers, gastric, and melanomas (144-145). IL-1 $\beta$ participates in carcinogenesis process via its ability in production of angiogenc and pro-metastatic factors such as VEGF, IL-8, IL-6, TNF $\alpha$, and TGF $\beta$ (146). IL-1 $\beta$ can induce neoplasia in stomach and direct gastric inflammation to gastric cancer in NF- $\kappa \mathrm{B}$ - dependent way. HIF-1 $\alpha$ expression is up-regulated by $\mathrm{NF}-\kappa \mathrm{B}$ and $\mathrm{COX}-2$ mediation and resulting in induction of VEGF expression (Figure 2). Therefore IL-1 $\beta$ is indicated as a potent angiogenic factor (147). The effect of IL-1 $\beta$ on expression of MMPs proves its role in matrix degradation, cell migration, metastasis, and tissue remodeling; IL-1 $\beta$ may stimulate MMP9 via $\mathrm{p} 42 / \mathrm{p} 44$ MAPK, p38 MAPK, JNK, and NF- $\kappa$ B in airway inflammatory responses (148). H. pylori infectioninduced gastric cancer risk is correlated with gene polymorphisms in IL-1 $\beta$ (149). Investigation of stomach-specific human IL- $1 \beta$ in transgenic mice showed that IL-1 $\beta$ increases the risk of malignancies (150).

\section{VEGF}

Vascular endothelium growth factor (VEGF) is a critical factor in angiogenesis. Angiogenesis not only is a required step in tumorigenesis (151) but also is an important pathologic sign of inflammatory disorders such as rheumatoid arthritis (152). Several inflammatory cytokines such as IL-1 $\beta$, COX-2, IL-6, and oncostain $\mathrm{M}$ (OSM) induce the secretion of VEGF via HIF- $1 \alpha$ and NF- $\kappa$ B pathway. Thus following chronic inflammation and cytokines production, VEGF is generated and provide a pathway for angiogenesis/ oncogenesis (153) (Figure 
2). H. pylori infection increases the expression of VEGF-promoting angiogenesis and gastric cancer invasion. The participation of VEGF in gastric adenocarcinoma is highly mediated by COX-2 and NF-kB (154).

\section{Anti-inflammatory agents in order to treat cancer}

The close linking between inflammation and cancer especially gastric cancer lead to successful cancer treatment by antiinflammatory agents and also many anticancer agents are used to treat inflammation. NSAIDs are non-steroidal anti-inflammatory drugs contributing in cancer therapy and prevention via COX-2 inhibition. COX-2 contributes in carcinogenic processes due to its ability to augment the production of prostaglandins, convert procarcinogens to carcinogenic metabolites, inhibit apoptotic cell death, stimulate tumor angiogenesis, alter inflammatory and immune responses, and increase the invasion of cancerous cell. The preventive and treatment effects of NSAIDs-inhibiting COX-2 are detected on gastric cancer (155). Celecoxib is newer NSAIDs that called COX-2 inhibitors playing a major role in cancer prevention or monotherapy for cancer (156); the preventive effects of celecoxib on gastric cancer were proved in rats (157). Aspirin and celecoxib decreases gastric tumorigenesis by inhibiting Wnt signaling pathway. Nimesulide is a COX-2 inhibitor that has therapeutic effects on gastric cancer cells in Wnt inhibition-dependent way (158).

Besides the chemical drugs, there are a large number of herb/plant-derived natural products (capsaicin, resveratrol, various compounds in garlic, curcumin, ginsenosides) that decrease or prevent inflammation. Their possible antiinflammatory mechanisms containing: prevention of NF-kB, COX-1 and -2 , MAPK, JNK and ERK1/2 signaling pathway, decreasing VEGF, and iNOS that are resulted in inhibiting growth and proliferation and direct to apoptosis and cell cycle arrest (159). Curcumin is a well known therapeutic agent with antioxidant, antiinflammatory, analgesic and anti-septic activity. It has been demonstrated that curcumin vigorously affect on gastric cancers via preventing transcription of NF- $\mathrm{KB}$ and downregulates its target genes, Bcl-2, Bcl-xL (160).

\section{Conclusion}

Growing evidences indicate that there is a close connection between inflammation and cancer. Chronic inflammation is believed to cancer initiation and progression by number of cytokines. Genomic alterations such as DNA damage, increased DNA synthesis, block the repair pathway, and inhibit apoptosis may direct to chronic inflammation. Although considerable effort has been expended to clarify some pathways making a bridge between inflammation and cancer, there are some possible mechanisms that are still not elucidated. Further studies are needed to identify new pathways and/or detail unknown cross-talk and routs in the present mechanisms. This is important issue in human health since many therapeutic agents target signaling pathways. Therefore new achievements may represent novel therapeutic approaches or modify previous therapy intervention results. This in turn results in decreasing the incidence of inflammatoryinduced cancers, improves patient's chance of recovery and healing processes and also positively affects on inflammatory disorders.

\section{Acknowledgement}

We would like to thank Professor Tim Greten for his helpful discussion and critical advice on the manuscript.

\section{References}

1. Balkwill F, Mantovani A. inflammation and cancer: back to Virchow? Lancet. 2001; 357 (9255): 539-45. PMID: 11229684

2. Vendramini-Costa DB, Carvalho JE.Molecular link mechanisms between inflammation and cancer. Curr Pharm Des. 2012; 18 (26): 3831-52. PMID: 22632748

3. Nelson WG, De Marzo AM, DeWeese TL, Isaacs WB. The role of inflammation in the pathogenesis of prostate cancer. J Urol. 2004; 172 (5 Pt 2): S6-11. PMID: 15535435

4. Rothman I, Stanford JL, Kuniyuki A, Berger RE. Self-report of prostatitis and its risk factors in a random sample of middle-aged men. Urology. 2004; 64 (5): 876-9. PMID: 15533468

5. Pohl C, Hombach A, Kruis W. Chronic inflammatory bowel disease and cancer. Hepatogastroenterology. 2000; 47 (31): 57-70. PMID: 10690586

6. Pohl C, Hombach A, Kruis W. Chronic inflammatory bowel disease and cancer. Hepatogastroenterology. 2000; 47 (31): 57-70. PMID: 10690586

7. Farrow B, Sugiyama Y, Chen A, Uffort E, Nealon W, Mark Evers B. Inflammatory mechanisms contributing to pancreatic cancer development. Ann Surg. 2004; 239 (6): 763-9. PMID: 15166955

8. Stolte M, Meining A. Helicobacter pylori and gastric cancer. Oncologist. 1998; 3 (2): 124-8. PMID: 10388094

9. Mantovani A, Allavena P, Sica A, Balkwill F. Cancer-related inflammation. Nature. 2008; 454 (7203): 436-44. PMID: 18650914

10. Ferrero-Miliani L, Nielsen OH, Andersen PS and Girardin SE. Chronic inflammation: importance of NOD2 and NALP3 in interleukin-1b generation. Clin Exp Immunol. 2006; 147: 227-35. PMID: 17223962

11. Maślińska D, Gajewski M. Some aspects of the inflammatory process. Folia Neuropathol. 1998; 36 (4): 199-204. PMID: 10079600 
12. Markiewski MM, Lambris JD. The role of complement in inflammatory diseases from behind the scenes into the spotlight. Am J Pathol. 2007; 171 (3): 715-27. PMID: 17640961

13. Iwalewa EO, McGaw LJ, Naidoo V, Eloff JN. Inflammation: the foundation of disease and disorders. A review of phytomedicines of South African origin used to treat pain and inflammatory conditions. Afr J Biotechnol. 2007; 6 (25): 2868-85.

14. Kataranovski M, Magic Z, Pejnovic N. Early inflammation cytokines and acute phase protein response under the stress of thermal injury in rats. Physiol Res. 1999; 48 (6): 473-82. PMID: 10783913

15. Sethi G, Shanmugam MK, Ramachandran L, Kumar AP, Tergaonkar V. Multifaceted link between cancer and inflammation. Biosci Rep. 2012; 32 (1): 1-15. PMID: 21981137

16. Shaikh PZ. Cytokines \& their physiologic and pharmacologic functions in inflammation: A review. Int J of Pharm \& Life Sci. 2011; 2 (11): 1247-1263.

17. Aggarwal BB. Nuclear factor-kappa B: the enemy within Cancer Cell. 2004; 6 (3): 203-8. PMID: 15380510

18. Herra V, Parsonnet J. Helicobacter pylori and gastric adenocarcinoma. Clin Microbial Infect. 2009; 15 (11): 971-6. PMID: 19874380

19. Iizasa $H$, Nanbo A, Nishikawa J, Jinushi M, Yoshiyama $H$. Epstein-Barr Virus (EBV)-associated gastric carcinoma. Viruses. 2002; 4 (12): 3420-39. PMID: 23342366

20. Oguma K, Oshima H, Oshima M. Inflammation, tumor necrosis factor and Wnt promotion in gastric cancer development Future Oncol. 2010; 6 (4): 515-26. PMID: 20373866

21. Uemura N, Oomoto Y, Mukai T, Okamoto S, Yamaguchi $\mathrm{S}$, Mashiba $\mathrm{H}$, et al. Gastric corpus IL-8 concentration and neutrophil infiltration in duodenal ulcer patients. Aliment Pharmacol Ther. 1997; 11 (4): 793-800. PMID: 9305491

22. Eftang LL, Esbensen Y, Tannaes TM, Blom GP, Bukholm IRK, Bukholm G. Up-regulation of CLDN1 in gastric cancer is correlated with reduced survival. BMC Cancer. 2013; 13: 586 PMID: 24321518

23. Eck M, et al. CXC chemokines Gro (alpha)/IL-8 and IP10/MIG in Helicobacter pylori gastritis. Clin Exp Immunol. 2000; 122 (2): 192-9. PMID: 11091274

24. Tanko MN, Manasseh AN, Echejoh GO, Mandong BM, Malu AO, Okeke EN, et al. Relation between Helicobacter pylori, inflammatory (neutrophil) activity, chronic gastritis, gastric atrophy and intestinal metaplasia. Niger J Clin Pract. 2008; 11 (3): 270-4. PMID: 19140368

25. Shimoyama T, Fukuda S, Liu Q, Nakaji S, Fukuda Y, Sugawara K. Helicobacter pylori water soluble surface proteins prime human neutrophils for enhanced production of reactive oxygen species and stimulate chemokine production. J Clin Pathol. 2003; 56 (5): 348-51. PMID: 12719454

26. Rafiei A, Hosseni V, Janbabai G, Fazli B, Ajami A, Hossenikhah Z, Gilbert J, Merrell DS. Inducible nitrc oxide synthetase genotype and Helicobacter pylori infection affect gastric cancer risk. World J Gastroenterol. 2012; 18 (35): 4917-24. PMID: 23002365

27. Bauditz J, Ortner M, BierbaumM, Niedobitek G, Lochs H,
Schreiber S. Production of IL-12 in gastritis relates to infection with Helicobacter pylori. Clin Exp Immunol. 1999; 17 (2): 316. PMID: 10444264

28. Khansari N, Shakiba Y, Mahmoudi M. Chronic inflammation and oxidative stress as a major cause of age-related diseases and cancer. Recent Pat Inflamm Allergy Drug Discov. 2009; 3 (1): $73-$ 80. PMID: 19149749

29. Sarkar D, Fisher PB. Molecular mechanisms of agingassociated inflammation. Cancer Lett. 2006; 236 (1): 13-23. PMID: 15978720

30. Lodish H, Berk A, Zipursky SL, et al. Molecular Cell Biology. 4th edition. New York: W. H. Freeman; 2000.

31. Cantley LC, Neel BG. New insights into tumor suppression: PTEN suppresses tumor formation by restraining the phosphoinositide 3-kinase/AKT pathway. Proc Natl Acad Sci. 1999; 96 (8): 4240-45. PMID: 10200246

32. Anderson MW, Reynolds SH, Maronpot RM. Role of protooncogene activation in carcinogenesis. Environ Health Perspect. 1992; 98: 13-24. PMID: 1486840

33. Okumura T, Ericcksen RE, et al. K-ras mutation targeted to gastric tissue progenitor cells results in chronic inflammation, an altered microenvironment, and progression to intraepithelial neoplasia. Cancer Res. 2010; 70 (21): 8435-45. PMID: 20959488

34. Sparmann A, Bar-Sagi D. Ras-induced interleukin-8 expression plays a critical role in tumor growth and angiogenesis. Cancer Cell. 2004; 6 (5): 447-58. PMID: 15542429

35. Murakami Y, Watari K, Shibata T, Uba M, Ureshino H, et al. $\mathrm{N}$-myc downstream regulated gene 1 promotes tumor inflammatory angiogenesis through JNK activation and autocrine loop of interleukin-1 $\alpha$ by human gastric cancer cells. J Boil Chem. 2013; 288 (35): 25025-37. PMID: 23846687

36. Hofseth LJ, Ying L. Identifying, defusing weapons of mass inflammation in carcinogenesis. Biochim Biophys Acta. 2006; 1765 (1): 74-84. PMID: 16169156

37. Grivennikov SI, Greten FR, Karin M. immunity, inflammation, and cancer. Cell. 2010; 140(6): 883-99. PMID: 20303878

38. Fujiwara N, Kobayashi K. Macrophages in inflammation. Curr Drug Targets Inflamm Allergy. 2005; 4 (3):281-6. PMID: 16101534

39. Mantovani A, Sozzani S, Locati M, Allavena P, Sica A. Macrophage polarization: tumor-associated macrophages as a paradigm for polarized M2 mononuclear phagocytes. Trends Immunol. 2002; 23 (11): 549-55. PMID: 12401408

40. Coussens LM, Werb Z. Inflammation and cancer. Nature. 2002; 420 (6917): 860-67. PMID: 12490959

41. Lu H, Ouyang W, Huang C. Inflammation, A key event in cancer development. Mol Cancer Res. 2006; 4 (4): 221-33. PMID: 16603636

42. Schoppmann S, et al. Tumor-associated macrophages express lymphatic endothelial growth factors and are related to peritumoral lymphangiogenesis. Am J Pathol. 2002; 161 (3): 947-56. PMID: 12213723

43. Solinas G, Germano G, Mantovi A, Allavena P. Tumorassociated macrophages (TAM) as major players of the cancer- 
related inflammation. J Leukoc Biol. 2009; 86 (5): 1065-73. PMID: 19741157

44. Pollard JW. Tumour-educated macrophages promote tumour progression and metastasis. Nat Rev Cancer. 2004; 4 (1): 71-8. PMID: 14708027

45. Mantovani A, Bussolino F, Dejana E. Cytokine regulation of endothelial cell function. FASEB J. 1992; 6 (8): 2591-99. PMID: 14708027

46. DeNardo DG, Johansson M, Coussens LM. Immune cells as mediators of solid tumor metastasis. Cancer Metastasis Rev. 2008; 27 (1): 11-18. PMID: 18066650

47. Ohta M, Kitadai Y, Tanaka S, Yoshihara M, Yasui W, et al. Monocyte chemoattractant protein-1 expression correlates with macrophage infiltration and tumor vascularity in human gastric carcinomas. Int J Oncol. 2003; 22 (4): 773-8. PMID: 12632067

48. Haas W, Pereira P, Tonegawa S. Gamma/delta cells. Annu Rev Immunol. 1993; 11:637. PMID: 8476575

49. Singer A, Adoro S, Park JH. Lineage fate and intense debate: myths, models and mechanisms of CD4/CD8 lineage choice. Nat Rev Immunol. 2008; 8 (10): 788-801. PMID: 18802443

50. Corthay A. How do Regulatory T Cells Work? Scand J Immunol. 2009; 70 (4): 328-36. PMID: 19751267

51. Daniel D, Meyer-Morse N, Bergsland EK, Dehne K, Coussens LM, Hanahan D. Immune enhancement of skin carcinogenesis by CD4+ T cells. J Exp Med. 2003; 197 (8): 1017-28. PMID: 12695493

52. Bromwich EJ, McArdle PA, Canna K, et al. The relationship between T-lymphocyte infiltration, stage, tumour grade and survival in patients undergoing curative surgery for renal cell cancer. Br J Cancer. 2003; 89 (10): 1906- 8. PMID: 14612901

53. Canna K, McArdle PA, McMillan DC, et al. The relationship between tumor T-lymphocyte infiltration, the systematic inflammatory response and survival in patients undergoing curative resection for colorectal cancer. Br J Cancer 2005; 92 (4): 651- 4 PMID: 15700032

54. van den Berg A, Visser L, Poppema S. High expression of the CC chemokine TARC in Reed-Sternberg cells: a possible explanation for the characteristic T-cell infiltrate in Hodgkin's lymphoma. Am J Pathol. 1999; 154 (6): 1685-91. PMID: 10362793

55. O'Byrne KJ, Dalgleish AG. Chronic immune activation and inflammation as the cause of malignancy. Br J Cancer. 2001; 85 (4): 473-83. PMID: 11506482

56. Tan MP, Pedersen J, Zhan Y, Lew AM, et al. CD8+- T Cells Are Associated with Severe Gastritis in Helicobacter pyloriInfected Mice in the Absence of CD4+- T Cells. Infect Immun. 2008; 76 (3): 1289-97. PMID: 18025102

57. Sakaguchi S.Regulatory $\mathrm{T}$ cells in the past and for the future. Eur J Immunol. 2008; 38 (4): 901-37. PMID: 18395855

58. Ha TY. The role of regulatory $\mathrm{T}$ cells in cancer. Immune Netw. 2009; 9 (6): 209-235. PMID: 20157609

59. Kawaida H, Kono K, Takahashi A, Sugai H, Mimura $\mathrm{K}$, Miyagawa N, et al. Distribution of CD4+CD25high regulatory
T-cells in tumor-draining lymph nodes in patients with gastric cancer. J Surg Res. 2005; 124 (1): 151-7. PMID: 15734494

60. Kono K, Kawaida H, Takahashi A, Sugai H, Mimura $\mathrm{K}$, Miyagawa $\mathrm{N}$, et al. CD4 (+) CD25 high regulatory T cells increase with tumor stage in patients with gastric and esophageal cancers. Cancer Immunol Immunother. 2006; 55 (9): 1064-71. PMID: 16328385

61. Kandulski A, Malfertheiner P, Wex T.Role of regulatory Tcells in $\mathrm{H}$. pylori-induced gastritis and gastric cancer. Anticancer Res. 2010; 30 (4): 1093-103. PMID: 20530414

62. Nathan C. Neutrophils and immunity: challenges and opportunities. Nat Rev Immunol. 2006; 6 (3): 173-82. PMID: 16498448

63. Gong L, Cumpian AM, Caetano MS, Ochoa CE, et al. Promoting effect of neutrophils on lung tumorigenesis is mediated by CXCR2 and neutrophil elastase. Mol Cancer. 2013; 12 (1): 154. PMID: 24321240

64. Fridlender ZG, Albelda SM. Tumor-associated neutrophils: friend or foe? Carcinogenesis. 2012; 33 (5): 949-55. PMID: 22425643

65. Schmidt H, Bastholt L, Geertsen P, Christensen IJ, Larsen S, Gehl $J$, et al. Elevated neutrophil and monocyte counts in peripheral blood are associated with poor survival in patients with metastatic melanoma: a prognostic model. Br J Cancer. 2005; 93 (3):273-8. PMID: 16052222

66. Gregory AD, Houghton AM.Tumor-associated neutrophils: new targets for cancer therapy. Cancer Res. 2011; 71 (7): 2411-6. PMID: 21427354

67. Wroblewski LE, Peek RM Jr, Wilson KT. Helicobacter pylori and gastric cancer. factors that modulate disease risk. Clin Microbiol Rev. 2010; 23 (4):713-39. PMID: 20930071

68. Groot Kormelink T, Abudukelimu A, Redegeld FA. Mast cells as target in cancer therapy. Curr Pharm Des. 2009; 15 (16): 186878. PMID: 19519429

69. Huang B, Lei Z, Zhang GM, Li D, Song C, Li B, et al. SCFmediated mast cell infiltration and activation exacerbate the inflammation and immunosuppression in tumor microenvironment. Blood. 2008; 112 (4): 1269-79. PMID: 18524989

70. Mukherjee S, Bandyopadhyay G, Dutta C, Bhattacharya A, Karmakar R, Barui G. Evaluation of endoscopic biopsy in gastric lesions with a special reference to the significance of mast cell density. Indian J Pathol Microbiol. 2009; 52 (1): 20-4. PMID: 19136773

71. Zhang H, Wu J, Meng L, Shou CC. Expression of vascular endothelial growth factor and its receptors KDR and Flt-1 in gastric cancer cells. World J Gastroenterol. 2002; 8 (6): 994-8. PMID: 12439912

72. Viatour P, Merville M-P, Bours V, Chariot A. Phosphorylation of NF- $\mathrm{NB}$ and I $\kappa \mathrm{B}$ proteins: implications in cancer and inflammation. Trends Biochem Sci. 2005; 30 (1): 43-52. PMID: 15653325

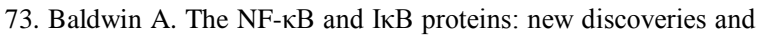
insights. Annu Rev Immunol. 1996; 14: 649-83. PMID: 8717528

74. Li Q, Verma IM. NF- $\kappa B$ regulation in the immune system. Nat Rev Immunol. 2002; 2 (10): 725-34. PMID: 12360211 
75. Lin A, Karin M. NF- $\kappa B$ in cancer: a marked target. Semin Cancer Biol. 2003; 13 (2): 107-14. PMID: 12654254

76. Karin M, Cao Y, Greten FR, Li ZW. NF- $\kappa B$ in cancer: from innocent bystander to major culprit. Nat Rev Cancer. 2002; 2 (4): 301-10. PMID: 12001991

77. Bond M, Fabunmi RP, Baker AH, Newby AC. Synergistic upregulation of metalloproteinase- 9 by growth factors and inflammatory cytokines: an absolute requirement for transcription factor NF-kappa B. FEBS Lett. 1998; 435 (1): 29-34. PMID: 9755853

78. Huang S, Robinson JB, Deguzman A, Bucana CD, Fidler IJ. Blockade of nuclear factor-kappaB signaling inhibits angiogenesis and tumorigenicity of human ovarian cancer cells by suppressing expression of vascular endothelial growth factor and interleukin 8 . Cancer Res. 2000; 60 (19): 5334-9. PMID: 11034066

79. Aihara M, Tsuchimoto D, Takizawa H, Azuma A, Wakebe H, Ohmoto Y, et al. Mechanisms involved in Helicobacter pyloriinduced interleukin-8 production by a gastric cancer cell line, MKN45. Infect Immun. 1997; 65 (8): 3218-24. PMID: 9234778

80. Yasumoto K, Okamoto S, Mukaida N, Murakami S, Mai M, Matsushima K. Tumor necrosis factor alpha and interferon gamma synergistically induce interleukin 8 production in a human gastric cancer cell line through acting concurrently on AP-1 and NF-kBlike binding sites of the interleukin 8 gene. J Biol Chem. 1992; 267 (31): 22506-11. PMID: 1331059

81. Kwon HC, Kim SH, Oh SY, Lee S, Lee JH, Jang JS, et al. Clinicopathologic significance of expression of nuclear factor- $\kappa \mathrm{B}$ RelA and its target gene products in gastric cancer patients. World J Gastroenterol. 2012; 18 (34): 4744-50. PMID: 23002344

82. Tahara E. Abnormal growth factor/cytokine network in gastric cancer. Cancer microenviron. 2008; 1 (1): 85-91. PMID: 19308687

83. Jarnicki A, Putoczki T, Ernst M. Stat3: linking inflammation to epithelial cancer more than a gut felling? Cell Div. 2010; 5:14. PMID: 20478049

84. Fan Y, Mao R, Yang J. NF- $\kappa$ B and STAT3 signaling pathways collaboratively link inflammation to cancer. Protein Cell. 2013; 4(3):176-85. PMID: 23483479

85. Yu H, Pardoll D, Jove R. STATs in cancer inflammation and immunity: a leading role for STAT3. Nat Rev Cancer. 2009; 9 (11): 798-809. PMID: 19851315

86. Wang Z, Si X, Xu A, Meng X, Gao S, Qi Y, et al. Activation of STAT3 in human gastric cancer cells via interleukin (IL)-6-type cytokines signaling correlates with clinical implications. PLoS One. 2013; 8 (10): e75788. PMID: 24116074

87. Wang GL, Jiang BH, Rue EA, Semenza GL. Hypoxiainducible factor 1 is a basic-helix-loop-helix-PAS heterodimer regulated by cellular O2 tension. Proc Natl Acad Sci U S A. 1995; 92 (12): 5510-4. PMID: 7539918

88. Chan DA, Sutphin PD, Yen SE, Giaccia AJ. Coordinate regulation of the oxygen-dependent degradation domains of Hypoxia-Inducible Factor $1 \alpha$. Mol Cell Biol. 2005; 25(15): $6415-$ 26. PMID: 6024780

89. Imtiyaz HZ and Simon MC. Hypoxia-inducible factors as essential regulators of Inflammation. Curr Top Microbiol Immunol. 2010; 345: 105-20. PMID: 20517715
90. Kaidi A, Qualtrough D, Williams AC, Paraskeva C. Direct transcriptional up-regulation of cyclooxygenase-2 by hypoxiainducible factor (HIF)-1 promotes colorectal tumor cell survival and enhances HIF-1 transcriptional activity during hypoxia. Cancer Res. 2006; 66 (13): 6683-91. PMID: 16818642

91. Jung YJ, Isaacs JS, Lee S, Trepel J, Neckers L. IL-1h-mediated up-regulation of HIF-1 $\alpha$ via an NFKappaB /COX-2 pathway identifies HIF-1 as a critical link between inflammation and oncogenesis. FASEB J. 2003; 17 (14): 2115-7. PMID: 12958148

92. Nagy MA. HIF-1 is the Commander of Gateways to Cancer. J Cancer Sci Ther. 2011; 3 (2): 035-040.

93. Stoeltzing O, McCartyMF, Wey JS, Fan F, Liu W, Belcheva A, et al. Role of hypoxia-inducible factor $1 \alpha$ in gastric cancer cell growth, angiogenesis, and vessel maturation. J Natl Cancer Inst. 2004; 96: 946-56. PMID: 15199114

94. Cho HY, Reddy SP, Yamamoto M, Kleeberger SR. The transcription factor NRF2 protects against pulmonary fibrosis. FASEBJ. 2004; 18 (11): 1258-60. PMID: 15208274

95. Itoh K, Mochizuki M, Ishii Y, Ishii T, Shibata T, Kawamoto Y, et al. Transcription factor Nrf2 regulates inflammation mediating the effect of 15-Deoxy- $\Delta$ 12,14-prostaglandin J2. Mol Cell Biol. 2004; 24 (1): 36-45. PMID: 14673141

96. Arisawa T, Tahara T, Shibata T, Nagasaka M, Nakamura M, Kamiya Y, et al. Nrf2 gene promoter polymorphism and gastric carcinogenesis. Hepatogastroenterology. 2008; 55 (82-83): 750-4. PMID: 18613447

97. Tripathy P, Wang Y, Coussens M, Manda YR, Casey AM, Lin $\mathrm{C}$, et al. Activation of NFAT signaling establishes a tumorigenic microenvironment through cell autonomous and non-cell autonomous mechanisms. Oncogene. 2014; 33 (14): 1840-9. PMID: 23624921

98. Liu Z, Lee J, Krummey S, Lu W, Cai H, Lenardo MJ. The kinase LRRK2 is a regulator of the transcription factor NFAT that modulates the severity of inflammatory bowel disease. Nat Immunol. 2011; 12 (11): 1063-70. PMID: 21983832

99. Weigmann B, et al. The transcription factor NFATc2 controls IL-6-dependent $\mathrm{T}$ cell activation in experimental colitis. J Exp Med. 2008; 205 (9): 2099-110. PMID: 18710929

100. Pan M, Winslow M, Chen L, Kuo A, Felsher D, Crabtree GR Enhanced NFATc1 nuclear occupancy causes $\mathrm{T}$ cell activation independent of CD28 costimulation. J Immunol. 2007; 178 (7): 4315-21. PMID: 17371988

101. Kyttaris VC, Zhang Z, Kampagiannni Q, Tsokos GC. Calcium signaling in systemic lupus erytematosus $\mathrm{T}$ cells: a treatment target. Arthritis Rheum. 2011; 63 (7): 2058-66. PMID: 21437870

102. Tsokos GC, Moulton VR. Abnormalities of T cell signaling in systemic lupus erythematosus. Arthr Res Ther. 2011; 13 (2): 20715. PMID: 21457530

103. Mehta J, Genin A, Brunner M, Scalzi LV, Mishra N, Beukelman T, Cron RQ. Prolonged CD154 expression on pediatric Lupus CD4 T Cells Correlates with increased CD154 Transcription, increased NFAT activity, and glomerulonephritis. Arthritis Rheum. 2010; 62 (8): 2499-509. PMID: 20506525 
104. Diehl S, Krahl T, Rinaldi L, Norton R, Irvin CG, Rincón M. Inhibition of NFAT specifically in $\mathrm{T}$ cells prevents allergic pulmonary inflammation. J Immunol. 2004; 172(6): 3597-603. PMID: 15004161

105. Rao A, Luo C, Hogan PG. Transcription factors of the NFAT family: regulation and function. Annu Rev Immunol. 1997; 15: 707-47. PMID: 9143705

106. Viola JPB, Carvalho LDS, Fonseca BPF, Teixeira LK. NFAT transcription factors: from cell cycle to tumor development. Braz J Med Biol Res. 2005; 38 (3): 335-44. PMID: 15761612

107. Pan MG, xiong $\mathrm{Y}$, Chen F. NFAT gene family in inflammation and cancer. Curr Mol Med. 2013; 13 (4): 543-54. PMID: 22950383

108. Yokoyama K, Higashi H, Ishikawa S, Fujii Y, et al Functional antagonism between Helicobacter pylori CagA and vacuolating toxin $\mathrm{VacA}$ in control of the NFAT signaling pathway in gastric epithelial cells. Proc Natl Acad Sci USA. 2005; 102 (27): 9661-66. PMID: 15980153

109. Muller A, et al. Involvement of chemokine receptors in breast cancer metastasis. Nature 2001; 410 (6824): 50-56. PMID: 11242036

110. Giraudo E, Inoue M, Hanahan D. An amino-bisphosphonate targets MMP-9-expressing macrophages and angiogenesis to impair cervical carcinogenesis, J Clin Invest. 2004; 114 (5): 623 33. PMID: 15343380

111. Lee HJ, Song IC, et al. CXC chemokines and chemokine receptors in gastric cancer: From basic findings towards therapeutic targeting. World J Gastroenterol. 2014; 20 (7): 168193. PMID: 3930968

112. Rossi D, Zlotnik A. The biology of chemokines and their receptors. Annu Rev Immunol. 2000; 18: 217-42. PMID: 10837058

113. Richmond A. NF-Kb, Chemokine gene transcription and tumor growth. Nat Rev Immunol. 2002; 2 (9):664-74. PMID: 12209135

114. Chung H, Lim JB. Role of the tumor microenvironment in the pathogenesis of gastric carcinoma. World J Gastroenterol. 2014; 20 (7): 1667-80. PMID: 24587646

115. Mashino, K. et al. Expression of chemokine receptor CCR7 is associated with lymph node metastasis of gastric carcinoma. Cancer Res. 2002; 62 (10): 2937-41. PMID: 12019175

116. Wu YY, Tsai HF, Lin WC, Hsu PI, et al. Upregulation of CCL20 and recruitment of CCR6+ gastric infiltrating lymphocytes in helicobacter pylori gastritis. Infect immune. 2007; 75(9): 435763. PMID:17562763

117. Seago ND, Clark DA, Miller MJ. Role of inducible nitric oxide synthase (iNOS) and peroxynitrite in gut inflammation. Inflamm Res. 1995; 44 (Suppl. 2): S153-4. PMID: 8548374

118. Hussain SP, Trivers GE, Hofseth LJ, et al. Nitric oxide, a mediator of inflammation, suppresses tumorigenesis. Cancer Res 2004; 64 (19): 6849-53. PMID: 15466171

119. Lala PK, Chakraborty C.Role of nitric oxide in carcinogenesis and tumour progression. Lancet Oncol. 2001; 2 (3): 149-56. PMID: 11902565
120. Rao CV. Nitric oxide signaling in colon cancer chemoprevention. Mutat Res. 2004; 555 (1-2): 107-19. PMID: 15476855

121. Kitadai $\mathrm{Y}$, Haruma $\mathrm{K}$, Goto $\mathrm{T}$, Komoto $\mathrm{K}$, Tanaka $\mathrm{S}$, Yoshihara M, et al. Gastric carcinoma and helicobacter pylori infection: role of nitric oxide and inflammatory cytokines in gastric carcinogenesis. Trends Gastrol Hepatol. 2001: 82-85.

122. Dubois RN, Abramson SB, Crofford L, Gupta RA, Simon LS, Van De Putte LB, Lipsky PE. Cyclooxygenase in biology and disease. FASEB J. 1998; 12 (12): 1063-73. PMID: 9737710

123. Jackson L, Evers BM. Chronic inflammation and pathogenesis of GI and pancreatic cancers. Cancer Treat Res. 2006; 130: 39-65. PMID: 16610702

124. Agoff SN, Brentnall TA, Crispin DA, Taylor SL, Raaka S, Haggitt RC, Reed MW, et al. The role of cyclooxygenase 2 in ulcerative colitis-associated neoplasia. Am J Pathol. 2000; 157 (3): 737-45. PMID: 10980113

125. Honjo S, Kase S, Osaki M, Ardyanto TD, Kaibara N, Ito H. Cyclooxygenase-2 expression in human gastric tubular adenomas and carcinomas; correlation with intratumoral microvessel density and apoptotic index. Anticancer Res. 2004; 24 (3a): 1439-44. PMID: 15274307

126. Cheng J, Fan XM. Role of cyclooxygenase-2 in gastric cancer development and progression. World J gastroenterol. 2013; 19 (42): 7361-68. PMID: 24259966

127. Balkwill F. Tumour necrosis factor and cancer. Nat Rev Cancer. 2009; 9 (5): 361-71. PMID: 19343034

128. Wu Y, Zhou BP. TNF- $\alpha / \mathrm{NF}-\kappa \mathrm{B} /$ snail pathway in cancer cell migration and invasion. Br J Cancer. 2010; 102 (4): 639-44. PMID: 20087353

129. Sethi G, Sung B, Aggarwal BB. TNF: a master switch for inflammation to cancer. Front Biosci. 2008; 13: 5094-107. PMID: 18508572

130. Zhao C, Lu X, Bu X, Zhang N, Wang W. Involvement of tumor necrosis factor- $\alpha$ in the upregulation of CXCR4 expression in gastric cancer induced by Helicobacter pylori. BMC Cancer. 2010; 10: 419. PMID: 20699000

131. Hodge DR, Hurt EM, Farrar WL. The role of IL-6 and STAT3 in inflammation and cancer. Eur J Cancer. 2005; 41(16): 2502-12. PMID: 16199153

132. Haura EB, Turkson J, Jove R. Mechanisms of disease: Insights into the emerging role of signal transducers and activators of transcription in cancer. Nat Clin Pract Oncol. 2005; 2(6):315-24. PMID: 16264989

133. Lin MT, Lin BR, Chang CC, Chu CY, Su HJ, Chen ST, et al. IL-6 induces AGS gastric cancer cell invasion via activation of the c-Src/RhoA/ROCK signaling pathway. Int J Cancer. 2007; 120 (12): 2600-8. PMID: 17304514

134. Lin WW, Karin M. A cytokine-mediated link between innate immunity, inflammation, and cancer. J Clin Invest. 2007; 117 (5): 1175-1183. PMID: 17476347

cff135. Witowski J, Ksiazek K, Jorres A. Interleukin-17: a mediator of inflammatory responses. CMLS, Cell Mol Life Sci. 2004; 61(5): 567-79. PMID: 15004696 
136. Wu D, Wu P, Huang Q, Liu Y, Ye J and Huang J. Interleukin17: A promoter in colorectal cancer progression. Clinical Dev Immunol. 2013; 2013: 436307. PMID: 24382972

137. Numasaki M, Fukushi J, Ono M, et al. Interleukin-17 promotes angiogenesis and tumor growth. Blood. 2003; 101 (7): 2620-27. PMID: 12411307

138. Wang L, Yi T, Kortylewski M, Pardoll DM, Zeng D, Yu H. IL-17 can promote tumor growth through an IL-6-Stat3 signaling pathway. J Exp Med. 2009; 206 (7):1457-64. PMID:19564351

139. Tartour E, Fossiez F, Joyeux I, Galinha A, Gey A, Claret E, et al. Interleukin 17, a T-cell-derived cytokine, promotes tumorigenicity of human cervical tumors in nude mice. Cancer Res. 1999; 59(15):3698-704. PMID: 10446984

140.Hirahara N, Nio Y, Sasaki S, Minari Y, Takamura M, Iguchi C , et al. Inoculation of human interleukin-17 gene-transfected MethA fibrosarcoma cells induces $\mathrm{T}$ cell-dependent tumor-specific immunity in mice. Oncology. 2001; 61 (1): 79-89. PMID: 11474253

141. Shibata $T$, Tahara $T$, Hirata $I$, Arisawa $T$. Genetic polymorphism of interleukin-17A and $-17 \mathrm{~F}$ genes in gastric carcinogenesis. Hum Immunol. 2009; 70 (7): 547-551. PMID: 19414056

142. Dai W, Zhou Q, Tan X, Sun C. IL-17A (-197G/A) and IL-17F $(7488 \mathrm{~T} / \mathrm{C})$ gene polymorphisms and cancer risk in Asian population: a meta-analysis. Onco Targets Ther. 2014; 7:703-11. PMID: 24868166

143. Rafiei A, Hosseini V, Janbabai G, et al. Polymorphism in the interleukin-17A promoter contributes to gastric cancer. World J Gastroenterol. 2013; 19 (34): 5693-99. PMID: 24039363

144. Voronov E, Shouval DS, Krelin Y, Cagnano E, Benharroch $\mathrm{D}$, Lwakura $\mathrm{Y}$, et al. IL-I is required for tumor invasiveness and angiogenesis. Proc Natl Acad Sci USA. 2003; 100 (5): 2645-50. PMID: 12598651

145. Elaraj DM, Weinreich DM, Varghese S, Puhlmann M, Hewitt SM, Carroll NM, et al. The role of interleukin I in growth and metastasis of human cancer xenografts. Clin Cancer Res. 2006; 12 (4): 1088-96. PMID: 16489061

146. Lewis A, Varghese S, Xu H, Alexander HR. Interleukin-1 and cancer progression: the emerging role of interleukin-1 receptor antagonist as a novel therapeutic agent in cancer treatment. J Transl Med. 2006; 4: 48 PMID: 17096856

147. Jung YJ, Isaacs JS, Lee S, Trepel J, Neckers L. IL-1 $\beta$ medited up-regulation of HIF-1 $\alpha$ via an NF- $\mathrm{KB} / \mathrm{COX}-2$ pathway identifies HIF-1 as a critical link between inflammation and oncogenesis. FASEB J. 2003; 17 (14): 2115-7. PMID: 12958148

148. Liang K, Lee CW, Lin WN, Lin CC, Wu CB, Luo SF, Yang CM. Interleukin-1beta induces MMP-9 expression via $\mathrm{p} 42 / \mathrm{p} 44$ MAPK, p38 MAPK, JNK, and nuclear factor-kappaB signaling pathways in human tracheal smooth muscle cells. J Cell Physiol. 2007; 211 (3): 759-70. PMID: 17311279
149. El-Omar EM, Rabkin CS, Gammon MD, Vaughan TL, Risch HA, Schoenberg JB, et al. Increased risk of noncardia gastric cancer associated with proinflammatory cytokine gene polymorphisms. Gastroenterology. 2003; 124 (5): 1193-201. PMID: 12730860

150. Tu S, Bhagat G, Cui G, Takaishi S, et al. Overexpression of interleukin-1 $\beta$ induces gastric inflammation and cancer and mobilizes myeloid-derived suppressor cells in mice. Cancer cell, 2008; 14 (5): 408-19. PMID: 18977329

151. Aonuma M, Iwahana M, Nakayama Y, Hirotani K, Hattori $\mathrm{C}$, Murakami K, et al. Tumorigenicity depends on angiogenic potential of tumor cells: dominant role of vascular endothelial growth factor and/or fibroblast growth factors produced by tumor cells. Angiogenesis. 1998; 2 (1):57-66. PMID: 14517376

152. Maruotti N, Cantatore FP, Crivellato E, Vacca A, Ribatti D. Angiogenesis in rheumatoid arthritis. Histol Histopathol. 2006; 21 (5): 557-66. PMID: 16493585

153. Angelo LS, Kurzrock R. Vascular endothelial growth factor and its relationship to inflammatory mediators. Clin Cancer Res. 2007; 13 (10): 2825-30. PMID: 17504979

154. Kitadai Y. Angiogenesis and lymphaniogenesis of gastric cancer. J Oncol. 2010; 2010: 468725. PMID: 20369064

155. Wang WH, Huang JQ, Zheng GF, et al. Non-steroidal antiinflammatory drug use and the risk of gastric cancer: A systematic review and meta-analysis. J Natl Cancer Inst. 2003; 95 (23): 178491. PMID: 14652240

156. Koki AT, Masferrer JL. Celecoxib: a specific COX-2 inhibitor with anticancer properties. Cancer Control. 2002; 9 (2 Suppl): 28-35. PMID: 11965228

157. Hu PJ, Yu J, et al. Chemoprevention of gastric cancer by celecoxib in rats. Gut. 2004; 53 (2): 195-200. PMID: 1774922

158. Periasamy J, Muthuswami M, Ramesh V, Muthusamy T, Jain A, et al. Nimesulide and Celecoxib inhibits multiple oncogenic pathways in gastric cancer cells. J Cancer Sci Ther. 2013; 5 (4): 126-36.

159. Rayburn ER, Ezell SJ, Zhang R. Anti-inflammatory agents for cancer therapy. Mol Cell Pharmacol. 2009; 1 (1): 29-43. PMID: 20333321

160. Yu LL, Wu JG, Dai N, Yu HG, Si JM. Curcumin reverses chemoresistance of human gastric cancer cells by downregulating the NF-kB transcription factor. Oncol Rep. 2011; 26 (5): 1197-203. PMID: 21811763 